\title{
Risiko Kredit, Risiko Pasar, Dan Kinerja Keuangan Perbankan Pada Masa Pandemi Covid-19
}

\author{
${ }^{1}$ Rini Dwi Astuti, ${ }^{2}$ Dewa Putra Krishna Mahardika \\ ${ }^{1}$ Program Studi Sarjana Akuntansi, Fakultas Ekonomi dan Bisnis, Universitas Telkom \\ ${ }^{2}$ Program Studi Sarjana Akuntansi, Fakultas Ekonomi dan Bisnis, Universitas Telkom \\ Email: ${ }^{1}$ rinidwi375@gmail.com, ${ }^{2}$ dewamahardika@telkomuniversity.ac.id
}

\begin{abstract}
The Covid-19 pandemic began to spread in Indonesia in March 2020. This caused a number of industrial sectors in Indonesia to experience a decrease in financial performance. One of the sectors that experienced a decline in financial performance was the banking sector. This study has purpose to determine the effect of credit risk and market risk on financial performance in commercial banks registered on the Indonesia Stock Exchange in the first until fourth quarters of 2020. The samples in this study is 35 banks. The sample is obtained by purposive sampling method. The method of analysis in this study is multiple linear regression analysis. From the results of the study, simultaneously credit risk and market risk affect financial performance. credit risk negatively affects financial performance. while market risk has a positive effect on financial performance.
\end{abstract}

Keywords: credit risk, market risk, and financial performance.

\section{PENDAHULUAN}

Virus Covid-19 memasuki Indonesia pada awal Maret 2020. Hal tersebut berdampak pada perekonomian hampir semua negara. Hampir seluruh sektor industri di Indonesia mengalami penurunan laba, bahkan menderita kerugian yang berakibat pada penurunan kinerja keuangan. salah satu sektor yang mengalami penurunan kinerja keuangan yaitu sektor perbankan. Hal tersebut dikarenakan meningkatnya jumlah kredit macet akibat debitur kesulitan membayarkan kreditnya. Peningkatan jumlah kredit macet akan berpengaruh terhadap kinerja keuangan bank.

Pada bulan Maret 2020 rasio Non-performing Loan gross terus meningkat sampai bulan Juni 2020. Rasio yang terus meningkat mengakibatkan OJK mengambil kebijakan untuk merestrukturisasi kredit nasabah. Nilai restrukturisasi ini mencapai 784,36 triliun rupiah. Nilai restrukturisasi tersebut berasal dari 6,73 juta nasabah. Disisi lain, pertumbuhan ekonomi nasional pada kuartal I hanya tumbuh sebesar 2,97\% (CNN Indonesia, 2020). Pada kuartal II pertumbuhan ekonomi nasional minus sebesar 5,32\%. Kinerja keuangan perbankan terus mengalami penurunan semenjak bulan Januari 2020 sampai bulan Juni 2020, walaupun sempat mengalami kenaikan di bulan Maret 2020. Berikut adalah perkembangan dari risiko kredit, pasar, serta kinerja keuangan pada bulan Januari sampai Juni 2020.

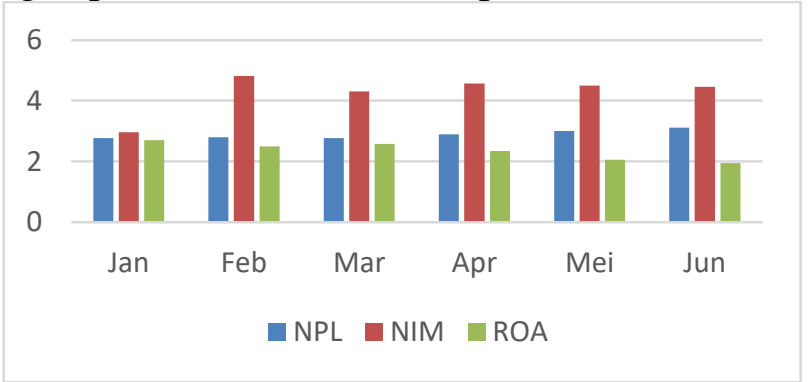

Gambar 1. NPL, NIM, dan ROA bulanJanuarisampaiJuni 2020

Sumber : www.ojk.go.id 
Dari fenomena di atas, maka diperlukan sebuah penelitian mengenai kinerja keuangan perbankan pada masa pandemi Covid-19. Tujuan penelitian ini yaitu mengetahui pengaruh risiko kredit dan pasar terhadap kinerja keuangan bank umum yang tercatat di Bursa Efek Indonesia pada triwulan I sampai IV tahun 2020. Otoritas Jasa Keuangan (OJK) mengatur tingkat kesehatan bank dalam peraturannya Nomor 4/POJK.03/2016 mengenai penilaian tingkat kesehatan bank umum.

Variabel independen pertama yaitu risiko kredit. Risiko kredit merupakan risiko yang terjadi karenadebitur atau pihak lain tidak mampu melaksanakan kewajibannya terhadap bank (Bank Indonesia, 2012). Secara umum, risiko kredit selalu ada di setiap kegiatan bank yang aktivitasnya berkaitan dengan kinerja pihak lawan, penerbit, serta peminjam dana. Risiko ini menggambarkan seberapa besar jumlah kredit bermasalah yang terdapat pada jumlah kredit secara keseluruhan. Pinjaman (kredit) yang bermasalah adalah pinjaman yang terdiri dari pinjaman kurang lancar, pinjaman diragukan, dan pinjaman macet. Tingginya nilai risiko kredit akan berdampak pada tingginya beban pencadangan aset produktif dan beban-beban lainnya. Hal tersebut akan berpengaruh pada kinerja keuangan bank (Natalia, 2015). Apabila kredit bermasalah memiliki nilai yang cukup besar, maka kinerja keuangan suatu bank cenderung akan menurun. Apabila kredit bermasalah memiliki nilai yang cukup kecil, maka cenderung terjadi peningkatan kinerja keuangan bank.

Risiko pasar merupakan risiko yang adapada kedudukan neraca dan rekening administratif yang mencakup kontrak derivatif, akibat peralihan keadaan pasar, termasuk risiko peralihan harga opsi (Bank Indonesia, 2012). Risiko pasar memiliki beberapa komponen yaitu suku bunga, ekuitas, kurs, serta komoditas. Risiko ini menggambarkan seberapa besar kemampuan manajemen menghasilkan penghasilan bunga bersih melalui aset produktif yang dimiliki bank. Nilai risiko pasar yang tinggi menunjukkan bahwa aset produktif mengasilkan pendapatan bunga yang tinggi, sehingga perusahaan juga akan memiliki kinerja keuangan yang tinggi.

Berdasarkan penjelasan yang telah diuraikan, maka penelitian ini mempunyai tiga pertanyaan penelitian yaitu, apakah risiko kredit dan risiko pasarberpengaruh terhadap kinerja keuangan perbankan pada masa pandemi Covid-19? Apakah risiko kredit berpengaruh terhadap kinerja keuangan perbankan pada masa pandemi Covid-19?Apakah risiko pasar berpengaruh terhadap kinerja keuangan perbankan pada masa pandemi Covid-19?

\section{LANDASAN TEORI}

Teori Sinyal

Teori ini dapat dapat diartikan sebagai pemberian sinyal yang dilakukan oleh perusahaan kepada pihak luar. Sinyal ini memiliki wujud dalam berbagai bentuk, yang dapat dilihat secara tidak langsung maupun secara langsung. Sinyal yang dikeluarkan perusahaan memiliki tujuan agar pihak luar dapat melakukan penilaian terhadap kondisi perusahaan. Teori sinyal dalam penelitian ini dapat dihubungkan dengan pihak manajemen bank yang menyerahkan suatu sinyal kepada pihak luar. Laporan keuangan, termasuk laporan tahunan serta laporan keuangan interim merupakan bentuk dari sinyal. Data pada laporan keuangan tersebut nantinya akan berguna bagi pihak luar, seperti sebagai bahan pertimbangan dalam keputusan investasi, data penelitian, dan lain-lain.

\section{Kinerja Keuangan}

Kinerja keuangan adalah penguraian suatu kondisifinansialpada waktu tertentu sehubungan dengan aspek pengumpulan dana maupun pendistribusian dana diukur menggunakan ukuran operasional, profitabilitas, dan likuiditas (Jumingan, 2014). Kinerja keuangan menggambarkan seberapa besar laba dihasilkan pada setiap rupiah aset yang dimiliki perusahaan. Anda dapat menganalisis laporan keuangan untuk mengukur kinerja keuangan yang dimiliki suatu perusahaan. 


\section{Risiko Kredit}

Setiap bank yang menyalurkan kredit kepada masyarakat akan menghadapi risiko kredit (Korompis et al., 2020). Risiko kredit adalah suatu risiko risiko yang timbul karena ketidakmampuan debitur serta pihak lain dalam melaksanakan kewajibannya terhadap bank (Bank Indonesia, 2012). Risiko ini berasal dari aktivitas fungsional bank. Aktivitas fungsional bank meliputi aktivitas treasury (membeli surat utang korporat), kredit, kegiatan investasi, trade finance (pembiayaan perdagangan) dan lain-lain. Risiko kredit menggambarkan seberapa besar perbandingan kredit bermasalah dari seluruh kredit yang diberikan. Tinggi rendahnya tingkat kinerja keuangan bank dapat dipengaruhi oleh tinggi rendahnya tingkat risiko kredit. Korompis et al. (2020) menemukan bahwa risiko kredit (NPL) berpengaruh signifikan dan mempunyai hubungan negatif terhadap profitabilitas (ROA) pada Bank yang Tercatat di LQ 45 periode 2012- 2018. Artinya semakin tinggi nilai risiko kredit maka semakin rendah profitabilitas suatu bank dan risiko kredit merupakan risiko yang penting dalam profitabilitas suatu bank.

H1: Risiko kredit berpengaruh negatif terhadap kinerja keuangan bank umum pada masa pandemi Covid-19.

\section{Risiko Pasar}

Risiko pasar terdapat pada kedudukan neraca serta rekening administratif yang mencakup kontrak derivatif, yang dikarenakan adanya peralihan keadaan pasar, termasuk risiko peralihan harga opsi (Bank Indonesia, 2012). Beberapa faktornya yaitu harga saham, tinggi rendahnya suku bunga bank, komoditas, nilai valuta asing, serta sekuritas. Risiko pasar menggambarkan seberapa besar pendapatan bunga dapat dihasilkan dari aset yang dimiliki oleh bank.Risiko pasar menggambarkankemampuan manajemen dalam mengelola aset produktif perusahaan guna mendapatkan penghasilan bunga bersih. Angka penghasilan bunga bersih yang semakin besar akan berakibat pada kinerja keuangan bank cenderung semakin tinggi. Korompis et al. (2020) menemukan bahwa risiko pasar (NIM) berpengaruh signifikan dan mempunyai hubungan positif terhadap profitabilitas (ROA) pada Bank yang Tercatat di LQ 45 periode 2012- 2018. Artinya, risiko pasar merupakan risiko yang penting dalam profitabilitas suatu bank dan dengan meningkatnya risiko pasar, demikian pula terjadi pada kinerja keuangan bank.

H2: Risiko pasar berpengaruh positif terhadap kinerja keuangan bank umum pada masa pandemi Covid-19.

\section{METODE PENELITIAN}

Penelitian ini merupakan penelitian dengan jenis penelitian kuantitatif dan berdata sekunder yang dihasilkan dari laporan keuangan bank. Populasi dalam penelitian ini adalah bank yang tercatat di Bursa Efek Indonesia. Penelitian ini bersampel sejumlah 35 bank diperoleh melalui metode purposive sampling. Ada empat kriteria untuk menentukan sampel penelitian. Kriteria pertama yaitu bank yang tercatat di Bursa Efek Indonesia pada triwulan I sampai I 2020. Kriteria kedua yaitu bukan merupakan bank pembangunan daerah. Kriteria ketiga yaitu tidak memiliki data outlier.

\section{Operasionalisasi Variabel Kinerja Keuangan}

Kinerja keuangan adalah uraian kondisi finansial pada waktu tertentu yang berkaitan dengan aspek pengumpulan dana maupun pendistribusian dana diukur menggunakan ukuran operasional, profitabilitas, dan likuiditas (Jumingan, 2014). Rumus Return On Asset (ROA) ialah proksi dari kinerja keuangan penelitian ini. ROA dapat memperlihatkan kecakapan manajemen dalam mengcapai laba yang diinginkan serta menggambarkan keefisiensian manajemen dalam mengelola aset (Korompis et al, 2020). 


\section{Risiko Kredit}

Risiko kredit adalah risiko yang terjadi akibat ketidakmampuan debitur atau pihak lain dalam melaksanakan kewajibannya terhadap bank (Bank Indonesia, 2012). Rasio Non Performing Loan (NPL) ialah proksi dari risiko kredit penelitian ini. Rasio NPL menggambarkan sejauh mana aktiva produktif yang dimiliki bank dapat memenuhi kredit bermasalah (Korompis et al, 2020).

\section{Risiko Pasar}

Risiko pasar merupakan risiko yang ada pada kedudukan neraca dan rekening administratif yang mencakup kontrak derivatif, akibat peralihan keadaan pasar, termasuk risiko peralihan harga opsi (Bank Indonesia, 2012). Rasio Net Interest margin digunakan sebagai proksi risiko pasar dalam penelitian ini. Risiko pasar dapat disebut risiko umum, karena sifatnya menyeluruh dan terjadi pada seluruh bank (Korompis et al, 2020).

\section{Teknik Analisis Data}

Regresi linear berganda ialah teknik analisis yang digunakan untuk menganalisis data penelitian ini. Menurut Ghozali (2018) analisis regresimemiliki tujuan menilai besarnyaketerikaran dua variabel atau lebih serta memperlihatkan arah keterikatan variabel penelitian. Berikut ialah rumus persamaan regresi dalam penelitian ini.

$$
\mathrm{Y}=\alpha+\beta 1 \mathrm{NPL}+\beta 2 \mathrm{NIM}+\mathrm{e}
$$

\section{HASIL DAN PEMBAHASAN Hasil Penelitian}

Penelitian ini memiliki tiga variabel, yaitu kinerja keuangan, risiko kredit, serta risiko pasar. Hasil pengujian statistik deskriptifnya disajikan dalam tabel di bawah ini.

Tabel 1. Statistik Deskriptif

\begin{tabular}{|c|r|r|r|}
\hline & ROA (Y) & NPL (X1) & NIM (X2) \\
\hline Rata-Rata & 1.0410 & 1.8791 & 2.3806 \\
\hline Std. dev & 1.1167 & 1.1048 & 1.6094 \\
\hline Maksimum & 3.64 & 4.95 & 7 \\
\hline Minimum & -4.61 & 0 & -0.95 \\
\hline n & 140 & 140 & 140 \\
\hline \multicolumn{2}{|c|}{ Sumber: Output IBM SPSS 25 } \\
\hline
\end{tabular}

Berdasarkan tabel di atas, variabel ReturnOnAsset (ROA) bernilai maksimum sejumlah $3,64 \%$ dan bernilai minimum sejumlah $-4,61 \%$. ROA berrata-rata $1.0410 \%$ dan berstandar deviasi $1.1167 \%$. Pada kondisi tersebut nilai rata-rata tdiak lebih dari nilai standar deviasi, artinya variabel ROA memiliki data yang bervariasi. Variabel Non-performing Loan (NPL) bernilai maksimum sejumlah $4,95 \%$ dan bernilai minimum sejumlah $0 \%$. Variabel NPL berratarata1,8791\% dan berstandar deviasi $1,1048 \%$. Pada kondisi tersebut nilai standar deviasi tidak lebih dari rata-rata, artinya variabel NPL memiliki data yang berkelompok. Variabel NetInterestMargin (NIM) bernilai maksimum sejumlah 7,00 \% dan bernilai minimum NIM sejumlah $-0,95 \%$. Pada tabel tersebut, variabel NIM berrata-rata 2,3806\% dan berstandar deviasi $1,6094 \%$. Pada kondisi tersebut rata-rata memiliki nilai lebih besar daripada standar deviasi, artinya variabel NIM memiliki data yang berkelompok. 


\section{Uji Asumsi Klasik \\ 1. Uji Normalitas}

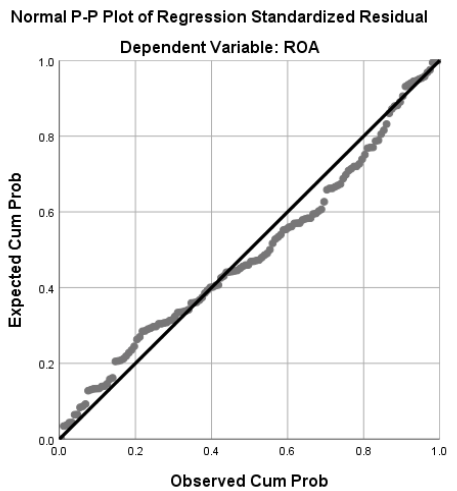

Sumber: Output IBM SPSS 25

Gambar 1. Hasil Uji Normalitas

Berdasarkan gambar tersebut, data penelitian terletak sekitar garis diagonal serta searah dengan garis. Disimpulkan bahwa data yang diuji, yaitu variable kinerja keuangan, risiko kredit, dan risiko pasar berdistribusi normal atau uji normalitas terpenuhi.

\section{Uji Multikolinearitas}

Tabel 2. Hasil Uji Multikolinearitas

\begin{tabular}{|c|l|r|r|}
\hline \multicolumn{2}{|l|}{ Model } & \multicolumn{2}{c|}{ Collinearity Statistics } \\
\cline { 3 - 4 } \multicolumn{2}{|c|}{} & Tolerance & VIF \\
\hline \multirow{2}{*}{1} & (Constant) & & \\
\cline { 2 - 4 } & NPL & .786 & 1.271 \\
\cline { 2 - 4 } & NIM & .786 & 1.271 \\
\hline
\end{tabular}

Sumber: Output IBM SPSS 25

Dari table tersebut, nilai tolerance dari seluruh variable tidak kurang dari 0,10. Selain itu, seluruh variable bernilai VIF kurang dari 10. Kesimpulannya, tidak terja dimultikolinearitas pada data yang diuji.

\section{Uji Autokorelasi}

Tabel 3. Hasil Uji Autokorelasi

\begin{tabular}{l|l} 
Model & Durbin-Watson \\
\hline 1 & 2.123 \\
\hline Sumber: Output IBM SPSS 25
\end{tabular}

Tabel tersebut menunjukkan bahwa nilai Durbin-Watson (DW hitung) bernilai sebesar 2,123. Dari tabel Durbin-Watson dengan $\mathrm{n}=140$ serta $\mathrm{k}=2$ pada tingkat signifikansi 5\%, didapatkan d U sebesar 1,753. Dari kriteria yang telah ditetapkan, nilai Durbin-Watson terdapat di antara 1,753-2,247, yaitu 1,753 $<2,123<2,247$. Sehingga dapat ditarik kesimpulan bahwa penelitian telah memenuhi uji autokorelasi.

\section{Uji Heteroskedastisitas}

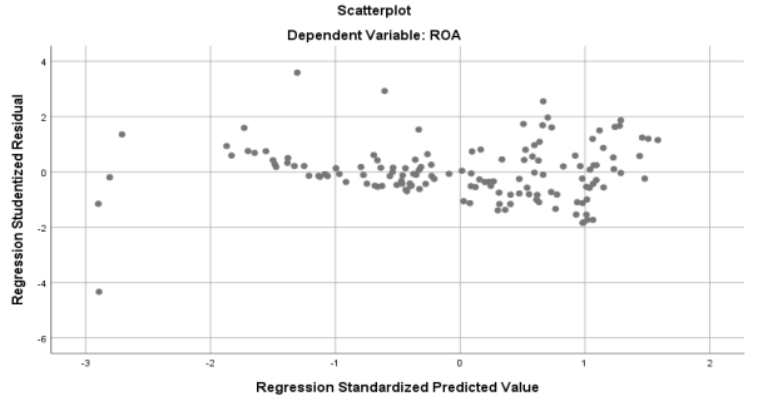

Sumber: Output IBM SPSS 25

Gambar2. Hasil Uji Heteroskedastisitas

http://e-journal.sari-mutiara.ac.id 
Kesimpulan dari gambar tersebut ialah tidak terjadi heteroskedastisitas pada model regresi. Hal itu terjadi karena titik-titik tersebar acak. Titik-titik tersebut juga tersebar secara acak pada sumbu Y baik di atas dan dibawah angka 0 , sehingga kesimpulannya ialah model regresi layak digunakan untuk meramalkan variabel kinerja keuangan menurut masukan variabel risiko kredit dan pasar.

\section{Analisis Regresi Linear Berganda}

Tabel 4. HasilAnalisisRegresi Linear Berganda

\begin{tabular}{|c|c|c|r|r|}
\hline \multicolumn{2}{|l|}{ Model } & \multicolumn{2}{|c|}{$\begin{array}{c}\text { Unstandardized } \\
\text { Coefficients }\end{array}$} & $\begin{array}{c}\text { Standardized } \\
\text { Coefficients }\end{array}$ \\
\cline { 3 - 5 } \multicolumn{2}{|c|}{} & \multicolumn{1}{c|}{ B } & Std. Error & Beta \\
\hline \multirow{2}{*}{1} & (Constant) & 1.112 & .287 & \\
\cline { 2 - 5 } & NPL & -.488 & .071 & -.482 \\
\cline { 2 - 5 } & NIM & .218 & .049 & .312 \\
\hline
\end{tabular}

Sumber: Output IBM SPSS 25

Analisis regresi linear berganda yang diperoleh dari tabel tersebut yaitu $\mathrm{ROA}=1,112-$ 0,488NPL + 0,218NIM + e. Dari persamaan tersebut, maka kesimpulannya:

1. konstanta NPL bernilai sebesar 1,112 berarti kinerja keuangan (ROA) bernilai sebesar 1,112 apabila risiko kredit (NPL) dan risiko pasar (NIM) bernilai nol;

2. nilai risiko kredit (NPL) sebesar $-0,488$ mengartikan bahwa setiap peningkatan 1 satuan risiko kredit (NPL), keuangan (ROA) akan menurun senilai 0,488 (asumsi variabel lainnya tidak berubah).

3. risiko pasar (NIM) bernilai sebesar 0,218 mengartikan bahwa setiap peningkatan 1 satuan risiko pasar (NIM), maka peningkatan juga terjadi pada kinerja keuangan (ROA) sebesar 0,218 (asumsi variabel lainnya tidak berubah).

\section{Hasil Uji Koefisien Determinasi}

Tabel 5. Hasil Uji Koefisien Determinast

\begin{tabular}{|l|r|r|r|r|}
\hline Model & \multicolumn{1}{|c|}{ R } & R Square & $\begin{array}{c}\text { Adjusted R } \\
\text { Square }\end{array}$ & $\begin{array}{c}\text { Std. Error of } \\
\text { the Estimate }\end{array}$ \\
\hline 1 & $.684^{\mathrm{a}}$ & .468 & .461 & .82196 \\
\hline
\end{tabular}

Sumber: Output IBM SPSS 25

Adjusted R Square pada tabel tersebut bernilai 0,461 atau 46,1\%. Hal itu menandakan bahwa pengaruh risiko kredit dan risiko pasar pada kinerja keuangan bank umum yang tercatat di Bursa Efek Indonesia triwulan I sampai IV tahun 2020 sebesar 46,1\% dan sisa dari angka tersebut sebesar 53,9\% menandakan bahwa kinerja keuangan dipengaruhi oleh variabel lain diluar penelitian.

\section{Hasil Uji Simultan}

Tabel 6. Hasil Uji Simultan

\begin{tabular}{|c|l|r|r|r|r|c|}
\hline \multicolumn{2}{|c|}{ Model } & $\begin{array}{c}\text { Sum of } \\
\text { Squares }\end{array}$ & df & $\begin{array}{c}\text { Mean } \\
\text { Square }\end{array}$ & F & Sig. \\
\hline \multirow{2}{*}{1} & Regression & 81.555 & 2 & 40.777 & 60.356 & $.000^{b}$ \\
\cline { 2 - 7 } & Residual & 92.559 & 137 & .676 & & \\
\cline { 2 - 7 } & Total & 174.114 & 139 & & & \\
\hline
\end{tabular}

\section{Sumber: Output IBM SPSS 25}

Nilai signifikansi yang dihasilkan pada tabel tersebut sebesar 0,000. Nilai tersebut kurang dari 0,05 . Kesimpulannya, $\mathrm{H}_{0}$ ditolak dan $\mathrm{H}_{\mathrm{a}}$ diterima. Jadi, secara simultan, risiko kredit dan risiko pasar berpengaruh terhadap kinerja keuangan. 


\section{Hasil Uji Parsial}

Tabel 7. Hasil Uji Parsial

\begin{tabular}{|c|c|c|c|c|c|c|}
\hline \multirow{2}{*}{\multicolumn{2}{|c|}{ Model }} & \multicolumn{2}{|c|}{$\begin{array}{l}\text { Unstandardized } \\
\text { Coefficients }\end{array}$} & \multirow{2}{*}{$\begin{array}{c}\text { Standardized } \\
\text { Coefficients }\end{array}$} & \multirow[t]{2}{*}{$\mathrm{t}$} & \multirow[t]{2}{*}{ Sig. } \\
\hline & & B & $\begin{array}{c}\text { Std. } \\
\text { Error }\end{array}$ & & & \\
\hline \multirow[t]{3}{*}{1} & (Constant) & 1.112 & .287 & & 3.871 & .000 \\
\hline & NPL & -.488 & .071 & -.482 & -6.855 & .000 \\
\hline & NIM & .218 & .049 & .312 & 4.446 & .000 \\
\hline
\end{tabular}

Sumber: Output IBM SPSS 25

Dari tabel di atas, diperoleh nilai koefisien risiko kredit (NPL) dengan arah (nilai beta) negatif sebesar -0,488 dan nilai signifikansi sebesar 0,000. Nilai tersebut tidak mencapai 0,05. Sehingga dapat disimpulkan bahwa $\mathrm{H}_{0}$ di tolak dan $\mathrm{H}_{\mathrm{a}}$ diterima. Hal tersebut berarti risiko kredit memiliki pengaruh negatif terhadap kinerja keuangan.

Nilai koefisien risiko pasar (NIM) dengan arah (nilai beta) positif sebesar 0,218 dan nilai signifikansi sebesar 0,000. Nilai signifikansi tersebut tidak mencapai 0,05. Sehingga dapat disimpulkan bahwa $\mathrm{H}_{0}$ di tolak dan $\mathrm{H}_{\mathrm{a}}$ diterima. Artinya risiko pasar berpengaruh positif terhadap kinerja keuangan.

\section{PEMBAHASAN}

Risiko kredit (NPL) memiliki beta negatif sebesar -0,488 dan nilai signifikansi sebesar 0,000. Nilai tersebut tidak mencapai 0,05. Sehingga dapat disimpulkan bahwa $\mathrm{H}_{0}$ di tolak dan $\mathrm{H}_{\mathrm{a}}$ diterima. Hal tersebut berarti risiko kredit memiliki pengaruh negatif terhadap kinerja keuangan. Penelitian ini memiliki hasil yang sama dengan penelitian Korompis et al. (2020). Korompis et al. (2020) menemukan risiko kredit (NPL) berpengaruh terhadap negatif terhadap kinerja keuangan (ROA). Berdasarkan statistik deskriptif, risiko kredit (NPL) memiliki nilai rata-rata yang dapat dikategorikan sangat sehat. Rendahnya nilai risiko kredit (NPL) akan meningkatkan kinerja keuangan (ROA) perbankan. Rendahnya risiko kredit akan berpengaruh terhadap peningkatan kinerja keuangan dan sebaliknya.

Risiko pasar (NIM) memiliki beta positif sebesar 0,218 dan nilai signifikansi sebesar 0,000. Nilai signifikansi tersebut tidak mencapai 0,05. Sehingga dapat disumpulkan bahwa $\mathrm{H}_{0}$ di tolak dan $\mathrm{H}_{\mathrm{a}}$ diterima. Artinya risiko pasar berpengaruh positif terhadap kinerja keuangan. Hasil penelitian ini sama dengan hasil penelitian Korompis et al. (2020) dan Ali (2017). Mereka juga menemukan risiko pasar (NIM) berpengaruh positif terhadap kinerja keuangan (ROA). Berdasarkan statistik deskriptif, risiko pasar (NIM) memiliki nilai rata-rata yang dapat dikategorikan sangat sehat. Tingginya nilai risiko pasar (NIM) akan meningkatkan kinerja keuangan (ROA) perbankan. Semakin tinggi risiko pasar (NIM) maka nilai rasio kinerja keuangan (ROA) suatu bank juga semakin tinggi dan sebaliknya.

\section{KESIMPULAN DAN SARAN \\ Kesimpulan}

1. Risiko kredit dan risiko pasar berpengaruh terhadap kinerja keuangan bank umum yang tercatat di Bursa Efek Indonesia triwulan I sampai IV tahun 2020.

2. Risikokredit berpengaruh negatif terhadap kinerja keuangan bank umum yang tercatat di Bursa Efek Indonesia triwulan I sampai IV tahun 2020.

3. Risikopasar berpengaruh positif terhadap kinerja keuangan bank umum yang tercatat di Bursa Efek Indonesia triwulan I sampai IV tahun 2020.

\section{Saran}

Berdasarkan kesimpulanyang sudah diuraikan, peneliti mempunyai saran untuk penelitian berikutnya diharapkan untuk memperluas populasi penelitian dengan menambahkan bank yang tidak tercatat di Bursa Efek Indonesia. Selain itu, peneliti berharap untuk penelitian selanjutnya dapat menambahkan variabel independen lainnya yang berhubungan dengan kinerja 
keuangan bank, sehingga penelitian dapat disempurnakan di masa yang akan datang.

\section{DAFTAR PUSTAKA}

Ali, M., \& Laksono, R. R. (2017). Pengaruh Net Interest Margin (NIM), Biaya Operasional Terhadap Pendapatan Operasional (BOPO), Loan To Deposit Ratio (LDR) Dan Non Performing Loan (NPL) Terhadap Return on Assets (ROA). Jurnal Riset Akuntansi \& Keuangan, 5(2), 1377-1392.

Anam, C. (2018). Pengaruh Risiko Kredit Dan Likuiditas Terhadap Kinerja Keuangan Perbankan Pada Bank Umum Konvensional Yang Tercatat Di BEI ( 2012-2016 ). Jurnal Bisnis Dan Perekembangan Bisnis, 2(2), 66-85.

Bank Indonesia. (2012). Kelembagaan Kesehatan Bank. Jakarta: Bank Indonesia

Harun, U. (2016). Pengaruh Ratio-Ratio Keuangan CAR, LDR, NIM, BOPO, NPL Terhadap ROA. Jurnal Riset Bisnis Dan Manajemen, 4(1), 67-82.

Ibrahim, Andi et al. (2018). MetodologiPenelitian. Makassar: Gunadarma Ilmu (Vol. 66).

Imam, G. (2018). Aplikasi Analisis Multivariate dengan Program IBM SPSS. Semarang: Badan Penerbit Universitas Diponegoro.

Jumingan. (2014). Analisis Laporan Keuangan. Jakarta: Bumi Aksara.

Korompis, R. R. N., Murni, S., Untu, V. N. Pengaruh Risiko Pasar (NIM), Risiko Kredit (NPL), dan Risiko Likuiditas (LDR) terhadap Kinerja Keuangan Perbankan (ROA) pada Bank yang Tercatat di LQ 45 Periode 2012-2018. Jurnal EMBA: Jurnal Riset Ekonomi, Manajemen, Bisnis Dan Akuntansi, 8(1), 175-184.

Oktavianus, C. Non Performing Loan Dan Net Interest Margin Terhadap Profitabilitas Perusahaan Perbankan Di Bursa Efek Indonesia. e Jurnal Katalogis, 4(8), 1-12.

Otoritas Jasa Keuangan. (2017). POJK Nomor 14/SEOJK.03/2017 Tentang Penilaian Tingkat Kesehatan Bank Umum. Peraturan Otoritas Jasa Keuangan, 33.

Sekaran, Uma; Bougie, R. (2016). Research Methods for Business. United Kingdom: WILEY (7th ed.).

Soetjati; Gusliana Mais, R. (2019). Analisis Faktor-faktor yang Mempengaruhi Profitabilitas Bank Umum di Indonesia (Studi pada Bank Umum Milik negara yang tercatat di BEI Periode 2014-2018). Jurnal Akuntansi Dan Manajemen, 16(01), 96-126.

Sugiyono. (2016). Metode Penelitian Kuantitatif, Kualitatif, dan R\&D (23rd ed.). Bandung: Alfabeta.

Trinugroho, I. \& Lau, E. (2019). Bussines Innovation and Development in Emerging Economies. London: Taylor \& Francis Group 